not affiliated with an academic institution. Funds are used for research that addresses a significant problem in political science.

The Selection Committee, composed of Gary Jacobson, University of California, San Diego, chair; Donna Bahry, University of California, Davis; David Brady, Stanford University; Roy F. Grow, Carleton College; Timothy Tilton, Indiana University; and Carole Uhlaner, University of California, Irvine, reviewed 32 applicants and made 11 awards. The grantees are:

Elizabeth W. Marvick, "Virginia's Founding Fathers as a Revolutionary Elite: Family Experience and Personality in Shaping the Institutions of the New Nation."

James W. McGuire, Wesleyan University, "Political and Economic Causes of Argentine Strikes, 19831989."

Donley T. Studlar, Oklahoma State University, "The Role of Minor Parties in the Political Recruitment of Women-The NDP in Canada."

Robert Dilger, University of the Redlands, "Residential Community Associations: Their Impact on American Governance."

John P. Burke, University of Vermont, "Coping with the Institutional Presidency: A Study of the White House Staff and Presidential Management Styles."

Gloria J. Braxton, Southern University, "Women, Power, and Influence in Liberia: Historical and Contemporary Perspectives."

Lee Ann Banaszak, Iowa State University, "The Swiss Women's Suffrage Movement, the State and Other Political Actors."

Patrick R. Ireland, Connecticut College, "Immigration in Western

Europe."

Huey L. Perry, Southern University, "Black Politics, Economic Development and Fiscal Policy Making in Two Southern Cities."'

Janna C. Merrick, St. Cloud State University, "Maternal-Fetal Rights: Adversaries or Allies?"

Alfredo Rehren, Universidad de Chile, "Executive Leadership and the
Redemocratization of Argentina, Chile and Uruguay."

\section{Ralph Bunche Summer Institute}

Twenty-five juniors who will be seniors this coming academic year were selected to participate in the fifth annual Ralph Bunche APSA Summer Institute in Political Science for Black Students, held June 11July 21 in Atlanta.

The Institute was conducted by a consortium consisting of Spelman College, Morehouse College, Georgia State University, and Emory University. Lois Moreland of Spelman was Director. Naomi Lynn of Georgia State, Tobe Johnson of Morehouse, and Eleanor Main and Micheal Giles of Emory were coordinators on their respective campuses.

The students selected as the winning participants came from diverse universities and colleges from 20 different states and the District of Columbia:

\section{Gayle Anderson, University of Portland}

Monique J. Bocock, University of Maryland, Baltimore County

Dorian L. Brown, Spelman College

Teresa J. Burl, University of

Arkansas, Little Rock

Dana M. Bush, Harvard University

Montrese M. Chandler, Howard

University

Daniella D. Daniel, Purdue

University

Ella M. Davis, University of North Alabama

Sherri Davis, Norfolk State

University

Doris M. Daye, North Carolina A\&T University

Stephen E. Hart, Oakland University

Kevin L. Hatcher, Grambling State University
Kimberly Henderson, Georgetown University

Tina F. Johnson, University of Alaska, Anchorage

Olivia A. Jones, Florida A\&M

University

Darrel T. King, Florida International University

Frances R. McNeal, University of Iowa

Barbara E. Rhodes, Mississippi College

Michael Ricks, Norfolk State University

Kimaria L. Seymour, University of Tennessee, Martin

James Smylie, Sangamon State University

Pamela M. Sutton, Washington University

LaTrice M. Washington, St. Augustine's College

Frank H. Williams, San Diego State University

Janell L. Wood, Western Kentucky University

Established in 1986, the Summer Institute is designed to encourage black students to pursue academic careers in political science. In prior years, the Institute was conducted in Baton Rouge, Louisiana by the Louisiana State University and Southern University.

The six-week program has five primary objectives:

- to introduce the participants to leading issues and problems in the discipline and profession of political science;

- to inform students of career opportunities for political scientists;

- to enhance the general academic skills of the participants, making them more competitive applicants for graduate school admission and financial assistance;

- to introduce students to quantitative and analytical methods of study in political science;

- to expose participants to leading scholars in the discipline. 